\title{
SPOTLIGHT ON
}

\section{The NEIMERLANDS}

IN THIS SECTION we will take you on a tour of some of the main areas within The Netherlands' Scientific Community. We will introduce you to various universities, institutes and companies showing their strengths and specialities.

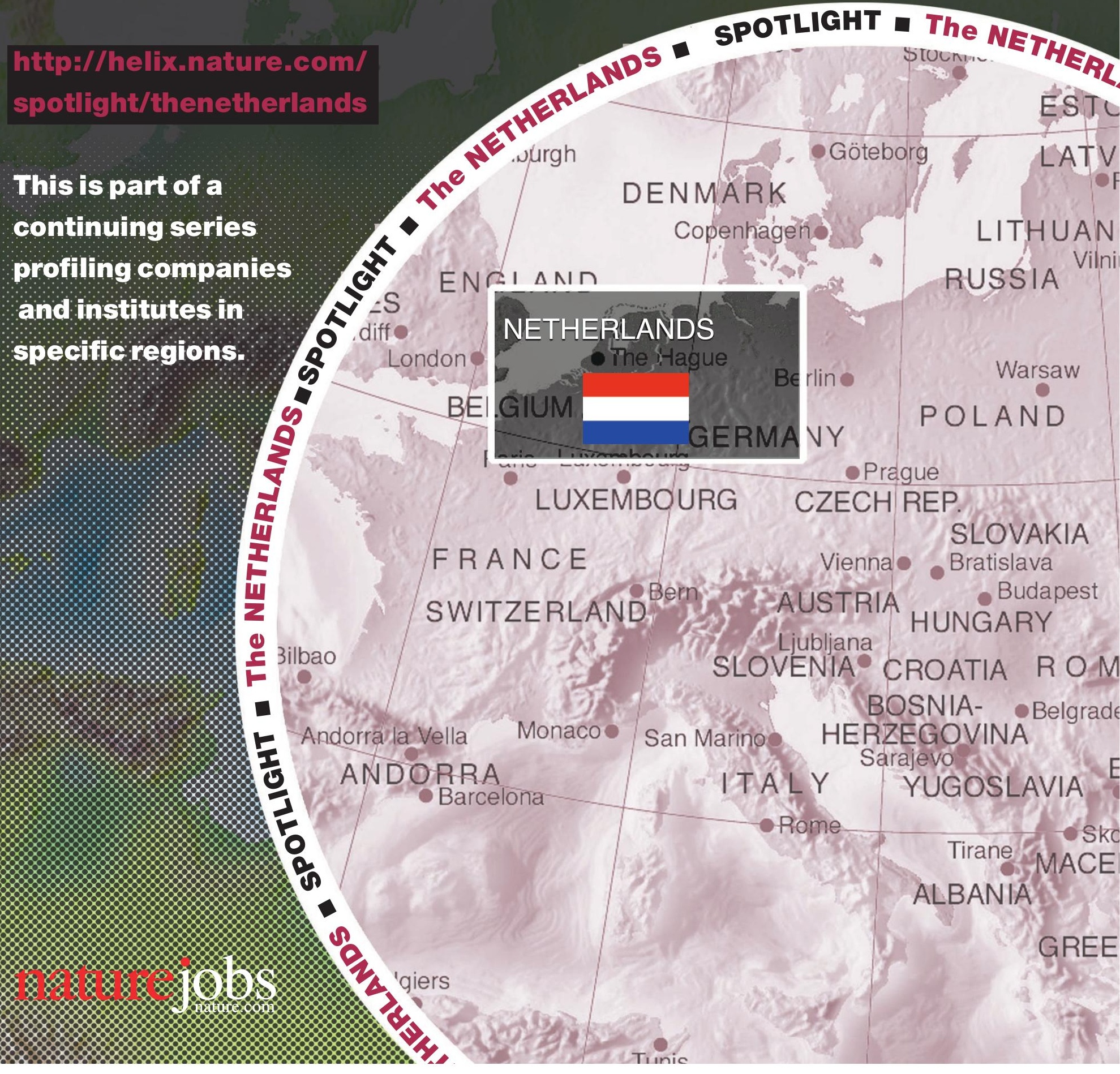




\begin{tabular}{|c|c|c|c|c|c|c|c|}
\hline Factor & Boston & Cambridge & Quebec & München & Belgium & Netherlands & Sweden \\
\hline Science base & •.... & •... & •.... & •... & •... & .... & ..... \\
\hline Culture & $\cdots \cdot \cdot$ & $\cdots \cdot$ & $\cdots$ & $\bullet$ & - & - & $\cdots$ \\
\hline Capital & .... & $\cdots \cdot \cdot$ & $\cdots$ & $\cdots$ & •・ & •• & $\cdot \cdot$ \\
\hline Environment & $\cdots \cdot \cdot$ & $\cdots$ & $\cdots \cdot$ & $\cdots$ & $\cdot \bullet$ & $\bullet$ & $\bullet$ \\
\hline Incubators & $\cdots \cdot$ & $\cdots$ & $\cdots$ & $\cdots$ & $\cdot \cdot$ & - & - \\
\hline Management & $\cdots \cdot$ & $\cdots \cdot$ & $\cdots$ & - & - & $\cdots$ & • \\
\hline
\end{tabular}

The result of this study was that the Dutch government designed a programme to overcome the distance between the Netherlands and regions such as Boston, USA and Cambridge, UK. Government involvement can be extremely beneficial for the development of new entrepreneurship in high tech. In Germany, where the government has a very generous policy on the support of start-ups in biotechnology, 450 new companies were created in life sciences since 1985, and the market capitalisation of German biotechnology rose from DM 4 billion in 1999 to DM 18 billion in 2000. The Dutch Ministry of Economic Affairs dedicated Dfl 100 million (approx. Euro $45 \mathrm{mln}$ ) for the period 20002004 to stimulate entrepreneurship in life sciences.

This Actionplan Life Sciences is now named BioPartner because people involved want to be a partner in the creation of new life sciences business. The money will be used in five instruments, aiming at the creation of new start-ups:

- BioPartner Network is dedicated to the stimulation and facilitation of entrepreneurship in life sciences in general in the Netherlands

- BioPartner First Stage Grant is a subsidy that can be obtained by a research organisation together with an employee. This employee can then dedicate up to two years to transferring a promising idea into a business plan

- BioPartner Facilities Support is designed as a revolving fund; the money provided can be used to buy equipment or facilities in an earlier stage than would be possible otherwise.

The money earned by using the equipment in contract research should provide for paying back the loan

- BioPartner Centers will be built in at least five towns; they will provide adequate housing, support, permits, facilities and so on for at least 10 startups in life sciences

- BioPartner Start-up Ventures gives seed money (for equity) to starters in life sciences, provided that other private investors invest similar amounts.

These five instruments should result in at least 75 new start-ups in life sciences on top of those that would have emerged without government support. The programme came into operation in the middle of 2000 and the first clients will have received their money by the end of 2000. In addition to the $\mathrm{Dfl} 100$ million of the Actionplan Life Sciences, the Dutch government will also provide research subsidies. In 2001 the Dutch government will decide on extra subsidies for genomics research.

\section{Masterclass Biobusiness}

Another initiative to stimulate business in Netherlands' Biotechnology Industry Association. This year, the association organized its third annual Masterclass Biobusiness in close co-operation with de Baak, Management Education Centre of VNO-NCW, one of the major Dutch employer's organisations.

This Masterclass offers biotechnological knowledge as well as managerial and entrepreneurial skill to everyone who wants to approach biotechnology in a more entrepreneurial way. It has already proven to be attractive and useful to many scientists. It will enhance the chance of success of biotech start-ups and make employees of larger companies more business-minded. Niaba and BioPartner have started talks to explore ways to organise the next Masterclass in 2001.

BioPartner, dr. ir. R.M. (Nettie) Buitelaar, tel. +313184784 54, e-mail buitelaar@biopartner.nl Niaba, drs. R.T.A. (Rob) Janssen, tel. +31703270464, e-mail janssen@niaba.vnci.nl

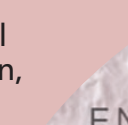

,

,
the Netherlands was taken by Niaba, the

\section{References}

1. Audretsch, D.B. and P. Stephen (1999) How and Why Does Knowledge Spill Over in Biotechnology?, in D.B. Audretsch and Roy Thurik (eds.) Innovation, Industry Evolution and Employment, Cambridge: Cambridge University Press, 216-229.

2. Audretsch, D.B. (2000) Recent development in US Biotechnology Clusters, paper prepared on behalf of the workshop on "Comparing the development of Biotechnology Clusters", Stuttgart, 27-28 January 2000

3. Eichener, V. (2000) Comparing BioTech Regions in Germany: Factors of Success. Paper prepared on behalf of the workshop on "Comparing the development of Biotechnology Clusters", Stuttgart, 27-28 January 2000

4. Saxenian, A. (1994) Regional Advantage, Cambridge, Mass. : Harvard University Press.

5. Swann, P. M. Prevezer and D. Stout (eds) (1998) The Dynamics of Industrial Change, Oxford: Oxford University Press.

6. Porter, M.E. (1998) Clusters and the New Economics of Competition, in: Harvard Business Review, Nov-Dec, p. 78.

7. Enzing, C.M., (2000), Monitoring and evaluation of the Life Science Action Plan, In Dutch, Internal report BioPartner

8. Lucas, P.A.A. (1998), Strategies for accelerating technology com-mercialisation in life sciences, MoretErnst \& Young For more information:

For Advertisers Index please turn to Page 13
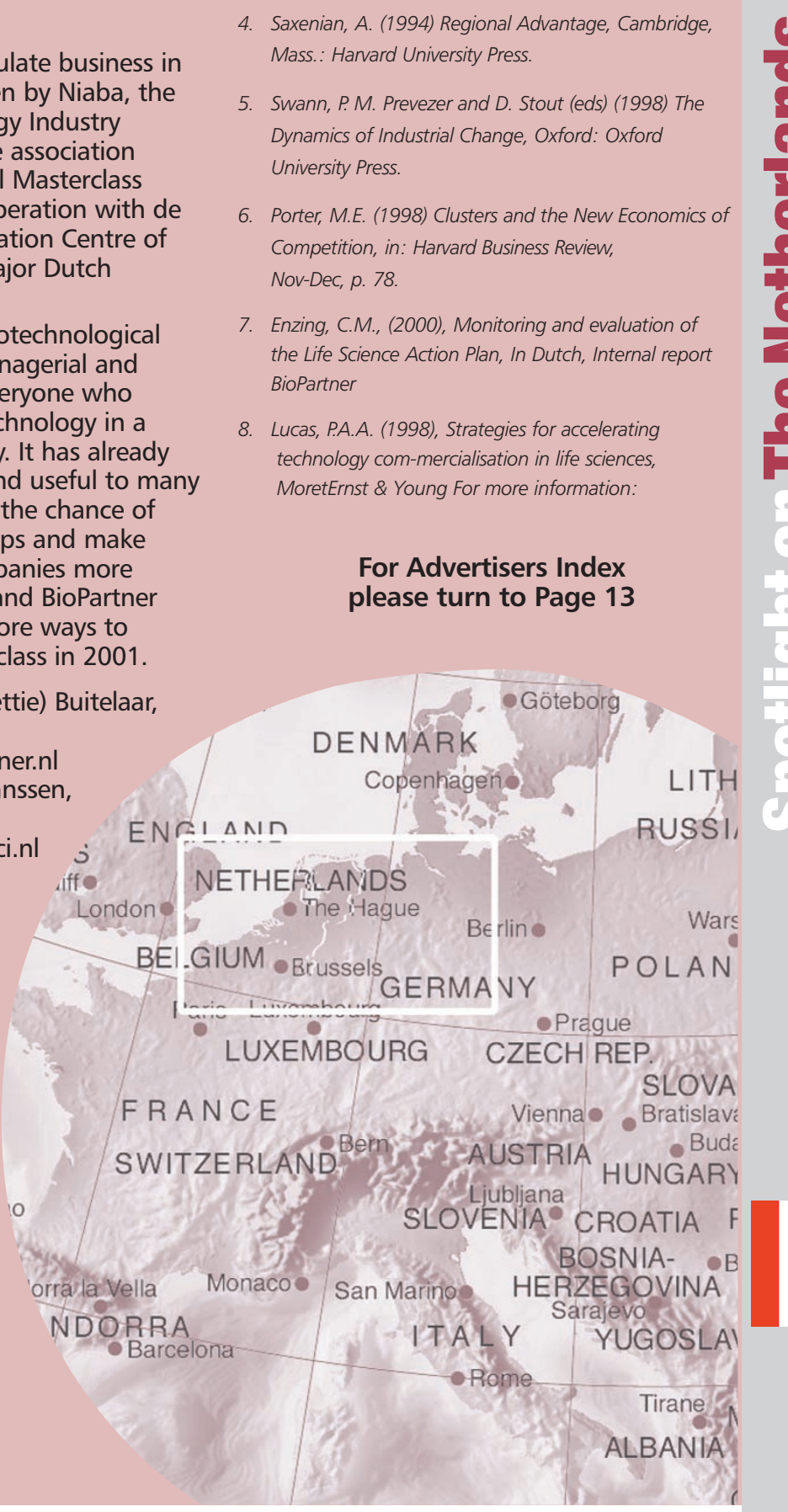


\section{Crucell}

Crucell N.v. is a Netherlands

based biotechnology company,

which was formed through the

merger between

IntroGene B.v. and

U-BiSys B.v. in

June, 2000.

Crucell is listed on

Euronext (Amsterdam) and on

the Nasdaq National Market

under ticker symbol "CRXL". 


\section{$\rightarrow$ The Company}

\section{Crucell's two widely applicable technologies}

Crucell has two widely applicable technologies: its human cell line expression platform, PER.C6, and its phage antibody-display library and related subtraction, selection and engineering technology, called MAbstract.

These two technologies provide Crucell with a powerful and effective means to discover, develop and produce a variety of biopharmaceuticals for the treatment of human diseases. The technologies are fully human and, as such, enable biopharmaceuticals to be developed and produced that do not have the limitations inherent in many biopharmaceuticals currently available.

\section{Crucell's partners}

Crucell has licensed its PER.C6 technology in the area of vaccines and gene therapy to 13 blue-chip pharmaceutical companies including Merck \& Co., Inc., GlaxoWellcome, Novartis (through its wholly-owned subsidiary, Systemix), and Pfizer/Warner-Lambert.

\section{Strategies}

Crucell has the ability to address all phases of human biopharmaceutical development from identifying drug targets through to commercial production. Our strategies focus on establishing PER.C6 as the production cell line of choice, discovering drug targets and developing therapeutic monoclonal antibodies, developing and commercializing own products and expanding the application of the two technology platforms through collaborations and strategic alliances.

\section{Research focus}

Our research activities related to human antibodies focus on the area of discovery and development of tumor-specific antibodies, angiogenesis, chronic inflammation and antibodies for vaccination strategies. Furthermore our research focusses on development of PER.C-flu, an influenza vaccine using the PER.C6 platform. In the area of gene therapy, we are developing our own products in the areas of cardiovascular disease and cancer.

Crucell currently employs approximately 115 people in its facilities in Leiden, Utrecht and Leuven (Belgium). We are actively seeking entrepreneurial, enthusiastic and highly skilled researchers and technicians to strenghten our teams in order to achieve the ambitious goals we have set for the future.

We offer excellent employment conditions such as a bonus arrangement and stockoptions. Furthermore, working for Crucell will provide you with the opportunity to work in a dynamic environment, for a fast growing company, potentially developing a new generation of medicines.
Crucell N.v.

Archimedesweg 4

2333 CN Leiden

P.O.Box 2048

2301 CA Leiden

The Netherlands

Phone: $\quad+31-71-5248701$

Fax: $\quad+31-71-5248702$

Info@crucell.com

www.crucell.com

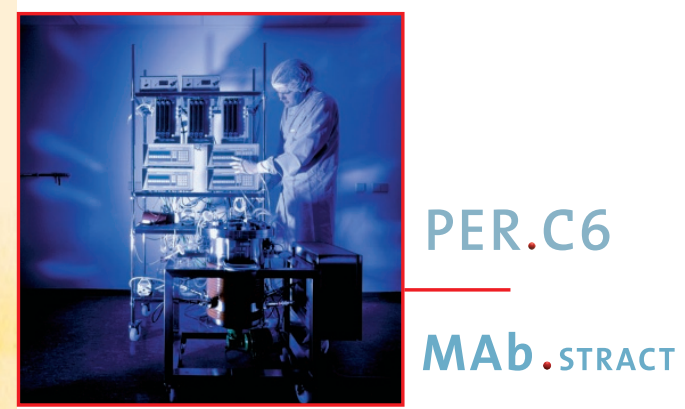

If you are interested in joining us, and you have a solid background in either molecular

(cell)biology, virology, immunology, oncology or gene therapy, please send your letter and CV to

Crucell N.v., attention

Mrs Hella J.M. Vroegop,

Manager Human Resources,

P.O. Box 2048,

2301 CA Leiden,

The Netherlands

Phone +31-71-52487 22,

or call Dinko Valerio,

President \& Chief Executive Officer

or Ton Logtenberg,

Executive Vice President \& Chief Scientific Officer Phone +31-71-524 8747 


\section{We simply have more to offer the Biotech business!}

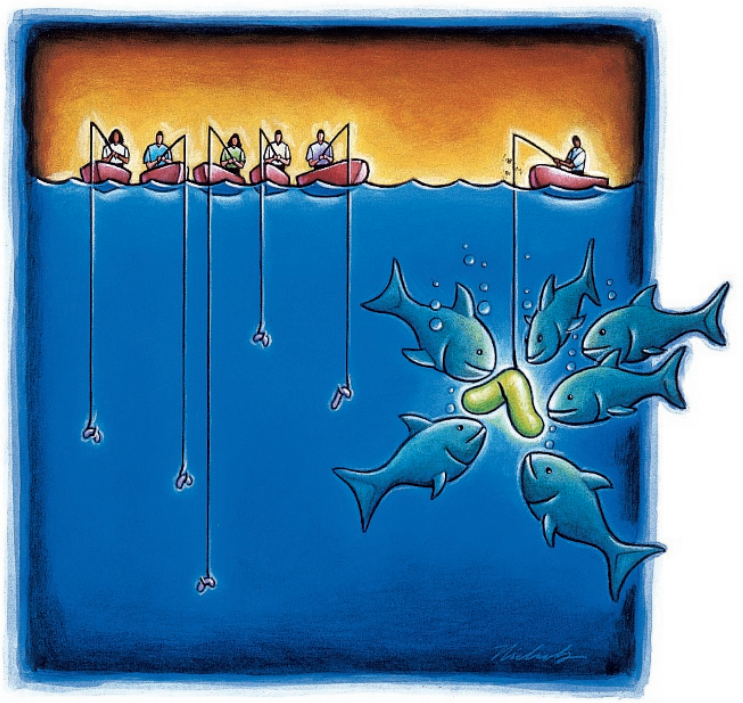

\section{The Netherlands -} your best catch in Europe.

We offer:

- A strategic business location

- Excellent technology infrastructure

- Superior logistics infrastructure

- Highly educated, multilingual \& flexible workforce

- Positive regulatory environment \& high level of public acceptance

- Distinguished scientific and academic communities

- Excellent support for start-ups

With over 20 years' experience in consulting and overseeing investment projects, we are committed to providing you with the best possible advice and assistance.

The Netherlands - Why settle for anywhere less?

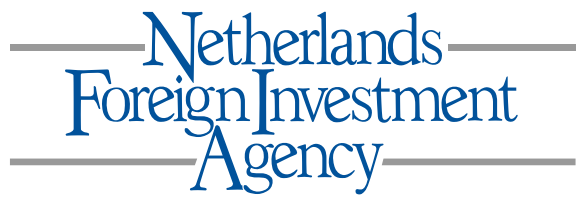

38 Hyde Park Gate London SW7 5DP United Kingdom Tell +44 (0)20 7225 I074 Fax +44 (0)20 75843396 email info@nfia.co.uk website www.nfia.co.uk

NFIA offices in North America E the Netherlands website www.nfia.com website www.nfia.nl

\section{Excellence in strategic research}
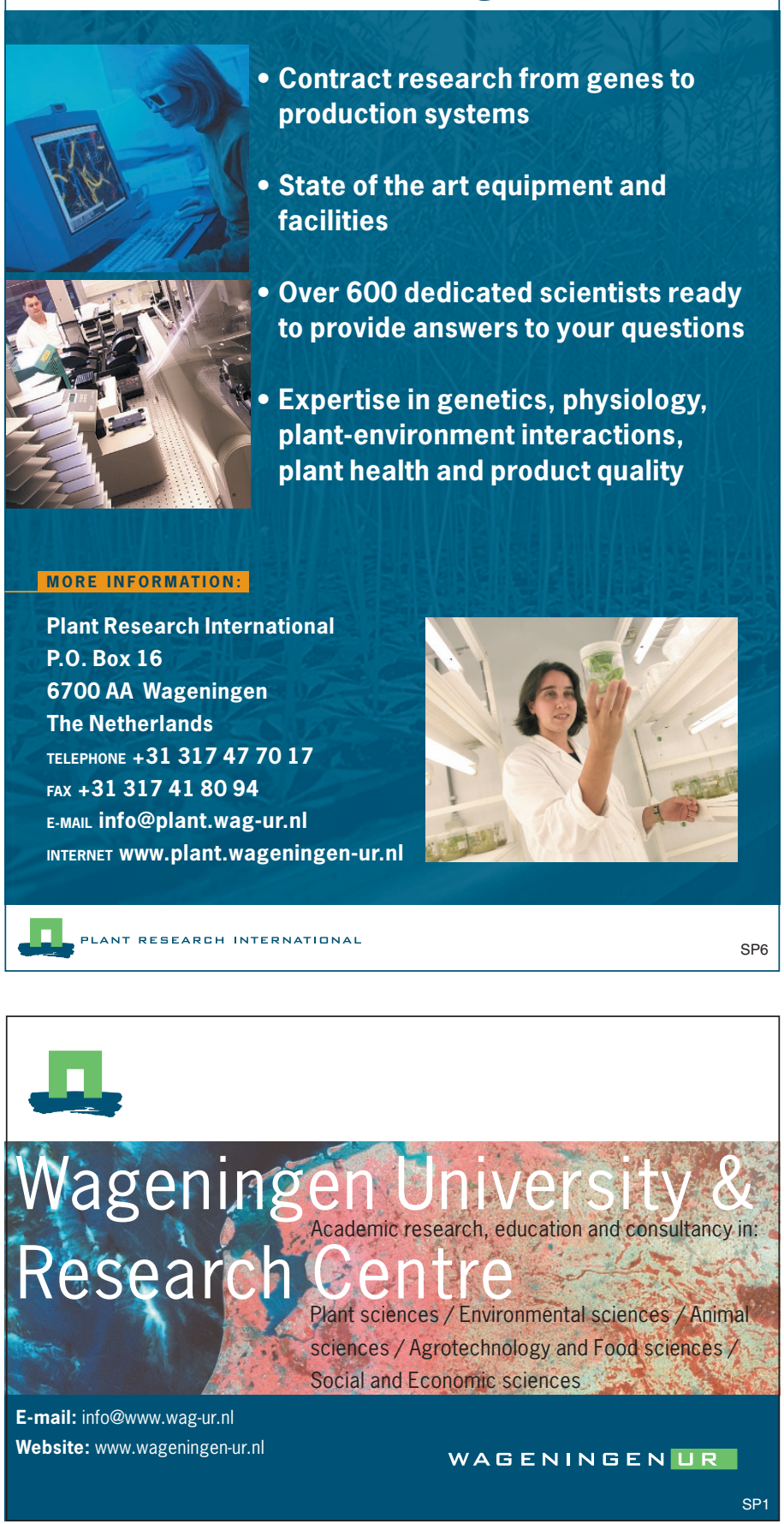

\section{ID-LELYSTAD}

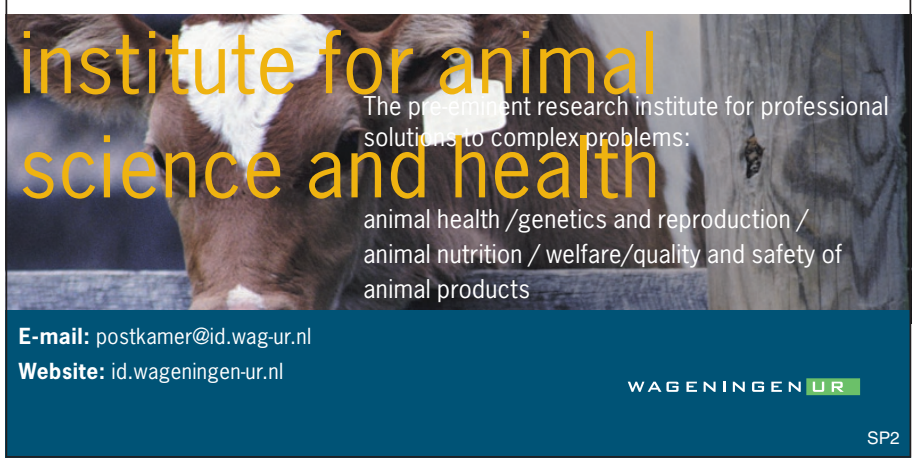

NATURE 7 DECEMBER 2000| www.nature.com 


\section{Universiteit Utrecht}

\section{Academic Biomedical Centre}

\section{From gene to patient, from molecule to man}

In the Academic Biomedical Centre - ABC, the deans of the faculties of Biology, Chemistry, Pharmacy and Veterinary Medicine of Utrecht University and the University Medical Centre Utrecht work closely together on biomedical research and education.

$A B C$ is a strong centre in multidisciplinary biomedical research in the Netherlands with various focal points of excellence and bringing together outstanding researchers. $A B C$ organizes shared facilities and a joint use of technolcgies, with respect to bioinformatics. In education, $A B C$ offers a varied number of programmes that bridge fundamental research and medical application.

\section{ABC research themes are}

Functional genomics and bio-informatics, Neurogenomics, Oncogenomics, Structural genomics and expression, Proteomics, advanced synthesis, functional and structural imaging, infection and immunity.

\section{ABC invests in highly qualified research and education by}

- Educating young people in the biomedical sciences through Bachelor, Master and PhD programmes;

- Providing an optimal climate for researchers, both academic staff and PhD-students, for excellent opportunities in research,

- Offering a synergetic research environment in the biomedical, biochemical and biological research with cpen access to facilities;

- Attracting qualified scholars of international prominence.

\section{Information and job vacancies}

$A B C$, Utrecht University, USP Research,

PO Box 8125,3503 TC Utrecht, The Netherlands. wwow.abc.uu.nl e-mail abcsiusp.uu.nl 


\section{BioMed City Groningen}
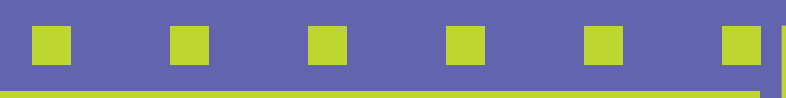

BioMed City Groningen is a virtual community of Life Science companies, knowledge institutions, and local authorities in the Northern Netherlands, with the aim of stimulating the Life Sciences in the region. BioMed City Groningen functions as the co-ordination point for all developments in the Northern Netherlands with regard to the Life Sciences, and ensures that the diverse activities in this field are appropriately counselled and coached. Its operations may vary from encouraging start-up firms to creating special facilities and arranging that the mutual networks of the largerscale companies and knowledge institutions are well integrated. Companies such as: Cordis (J \& J), Invitrogen, Pharma Bio Research, DSM Biologics, Yamanouchi, Intracel, Fresenius, and many others all participate in the Life Sciences network in the Northern Netherlands.

\section{Facts and Figures}

In the domain of the Life Sciences, the knowledge base in the Northern Netherlands is extremely comprehensive, and is primarily formed by the University of Groningen and the University Hospital. The knowledge base is a source of new development and also a source of well-educated personnel. The faculties of Natural Science and Medicine educate a total of almost 4,000 students in very diverse disciplines. The institutes of higher professional education in the Northern Netherlands educate a total of more than 3,000 students in the domain of the Life Sciences.

The University Hospital in Groningen (Academisch Ziekenhuis Groningen, AZG) provides almost 1100 beds and has a staff of 5,500. Approximately 26,000 patients are admitted to the hospital each year.

\section{Research focus \\ Neuro-imaging:}

The University of Groningen and Groningen University Hospital have decided to establish an integrated neuro-imaging centre that meets the highest international standards for brain research. New developments in data acquisition, visualisation methods, mathematical modelling, and image analysis emphasise the need for an integrated environment that allows the combined registration of neuronal signals. The objective is to create a neuro-imaging unit that will become one of the world's leading institutions in the area of dynamic brain research.

\section{Genotyping:}

The Northern Netherlands contains a large founder population (the term 'founder population' has been coined to denote a population with a common gene pool) of about 3 million people. Groningen University Hospital is the major reference centre of the catchment area comprising this particular population. This allows researchers in Groningen to study disease-related genomic profiles. To support this, a genome-screening facility has been established. The integrated system has enough capacity to determine 6 million genotypes per year. This is currently being combined with an infrastructure attuned to acquiring and processing relevant patient (and related normal control) samples These can be used both for the identification of gene sequences related to increased disease sensitivity and for assessing genomic profiles related to (in)sensitivity to the toxicity of (new) medicines.

\section{Facilities:}

To support the Life Sciences as much as possible, special buildings have been reserved in the medical complex - the University Hospital and the Faculty of Medicine - to simulate the exchange of information between companies, researchers, and clinics to a maximum extent.

At the same time, facilities have been created at the Zernike Science Park - near the Faculty of Mathematics and Natural Sciences - for a similar exchange between companies and research groups such as GBB, MsC, BioMaDe (nanotechnology), etc.

In addition to tangible facilities such as laboratory space and business sites specially oriented towards the Life Sciences, BioMed City Groningen can also mediate in attempts to obtain investment and R\&D subsidies, risk finance, and suchlike.

BioMed City Groningen • PO box 424 - 9700 AK Groningen • The Netherlands Tel: +31505214507 ·Fax: +31505214520 • E-mail: zuidema@nom.nl •www.biomedcity.nl
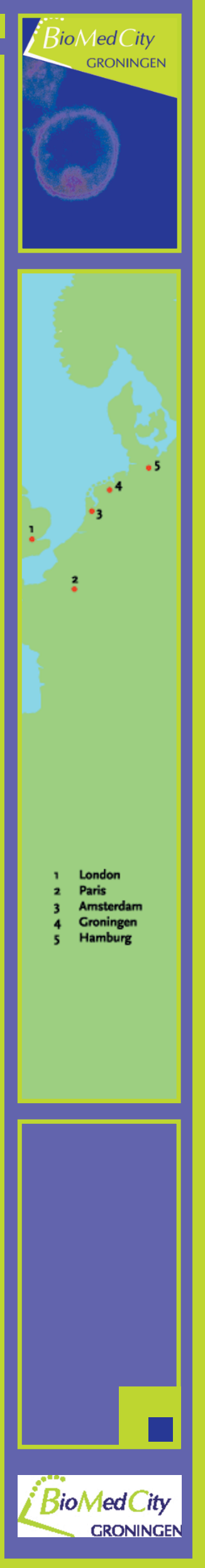


\section{Let nature be your teacher.

At Genencor, we've learned a lot from nature. It's through nature that we observe organisms and their molecular makeup so that we can mimic their unique properties to create our novel proteins. And these proteins will help us make drugs safer and more effective, cleaning products more powerful and enable the efficient production of chemicals. To learn more about us and what we do, log on to www.genencor.com.

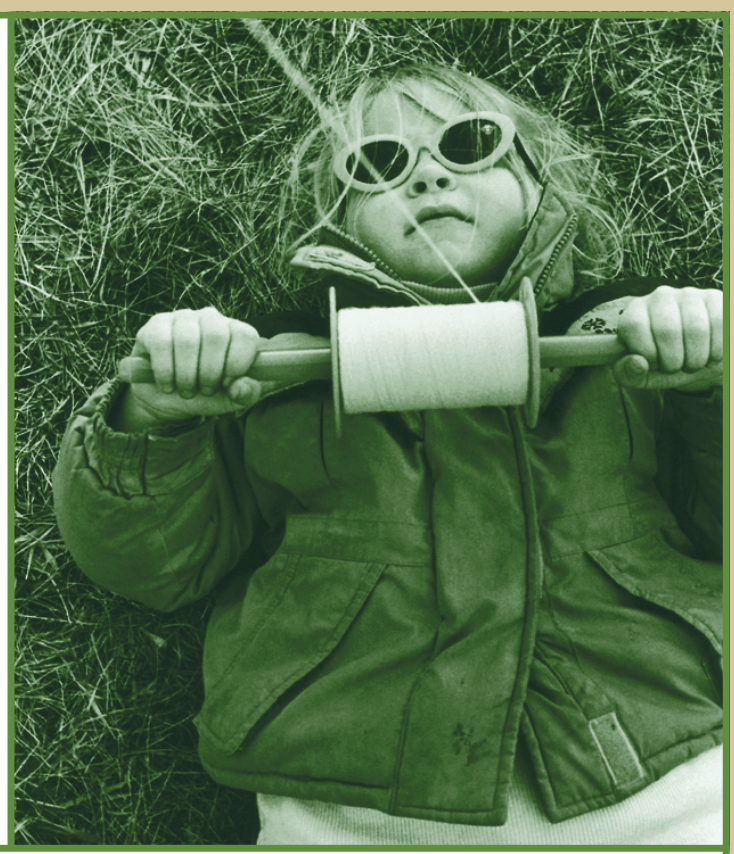

Genencor International, Inc. Innovative by Nature
Genencor, a diversified biotechnology company, uses integrated technology platforms to produce innovative products for a wide variety of industries. These platforms include gene discovery and functional genomics, human immunology, molecular evolution and design, metabolic pathway engineering, biomaterial production, and formulation delivery systems.

www.genencor.com - US Headquarters - Palo Alto, California - European Headquarters - Leiden, the Netherlands

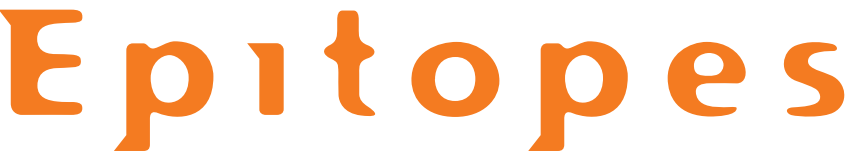

the key to protein-protein interactions
PEPSCAN

S Y S T E M S

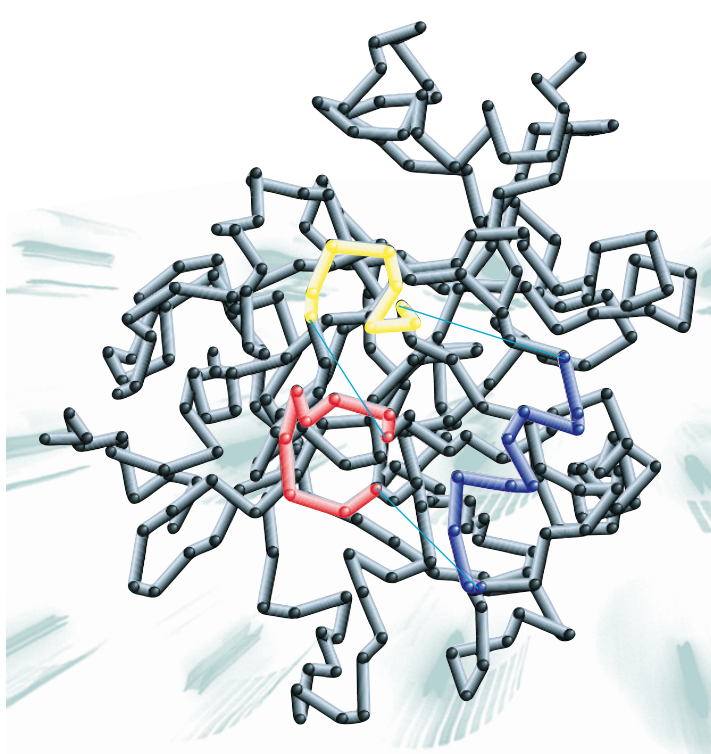

Characterisation of the 3-D structure of epitopes and corresponding functions of proteins.

State-of-the-art epitope mapping capabilities

Pepscan Systems' technology allows the characterisation of epitopes in a much more sophisticated and cost-effective way than previously possible.

\section{Discontinuous epitope mapping}

- Linear epitope mapping

Lead optimisation capabilities

Pepscan Systems' advanced technology platform combines highly effective conformational epitope mapping technologies with combinatorial peptide chemistry and powerful drug design techniques for lead optimisation purposes of biologically active peptides.

- Combinatorial peptide arrays

- Bio-informatics

- Peptidomimetics

Pepscan Systems Edelhertweg 15 8219 PH Lelystad The Netherlands
Tel: +31 (0) 320237200 Fax: +31 (0) 320238120
E-mail: p.vandijken@pepscan.nl Internet: www.pepscan.nl 


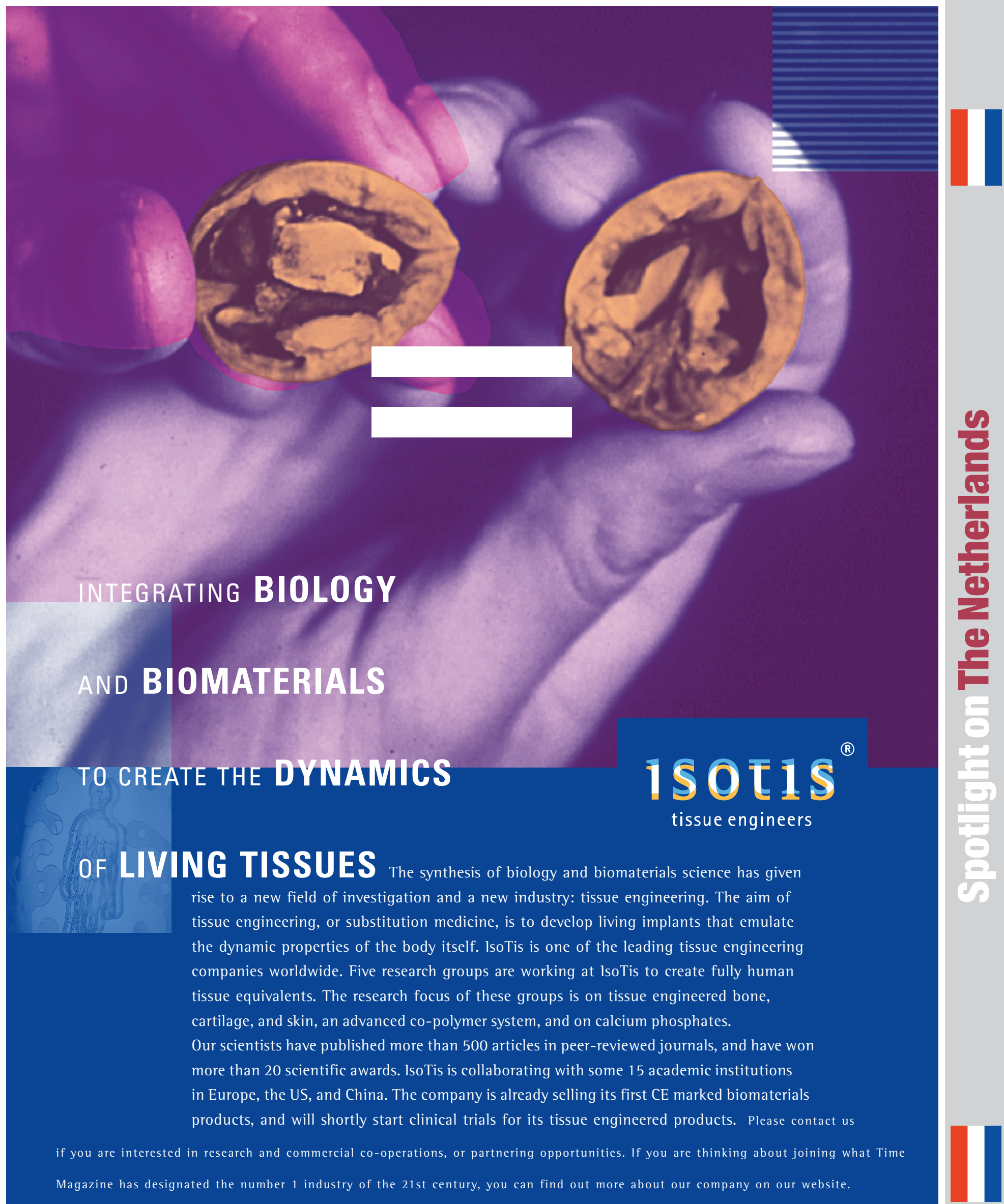




\section{THE BIO SCIENCE PARK | LEIDEN}

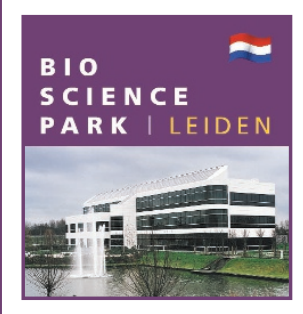

The Leiden area is rapidly becoming a nodal point for medical and scientific research. The presence of the Leiden University, the Leiden University Medical Center (LUMC) and an increasing number of joint ventures between business and academic/scientific research bodies creates a dynamic atmosphere that encourages the exchange of information and the optimal use of the latest technology.

The Leiden Bio Science Park has become, since its establishment twelve years ago, one of the most successful Science Parks in the Netherlands. It currently accommodates over sixty innovative knowledge-intensive companies with a wide range of specializations, including biotechnology, medical technology and space technology.

The Bio Science Park forms an international high-tech industrial and research-based cluster, providing an excellent environment for the growth of innovative large and small-scale firms. For example: Centocor Europe, Fokker Space, Nalco Chemical, Zeneca Mogen, Pharming, Introgene, OctoPlus, TNO and the Centre for Human Drug Research. And nearby engineering companies like Jacobs Engineering and Heerema.

In the Bio Science Park, scientific research is combined with commercial activities. The Academic Business Centre facilitates co-operation between academic institutions and the business community at both national and international level.

The Bio Science Park's high standard of research is maintained through close association with the neighbouring Leiden University, internationally acclaimed for exceptional education and research. The Leiden University is not only the oldest established university in Europe, but also one of the most respected.

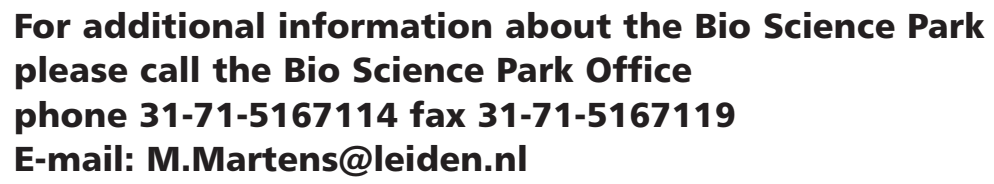

WAGENINGENUR

\section{Greenomics $^{\mathrm{TM}}$}

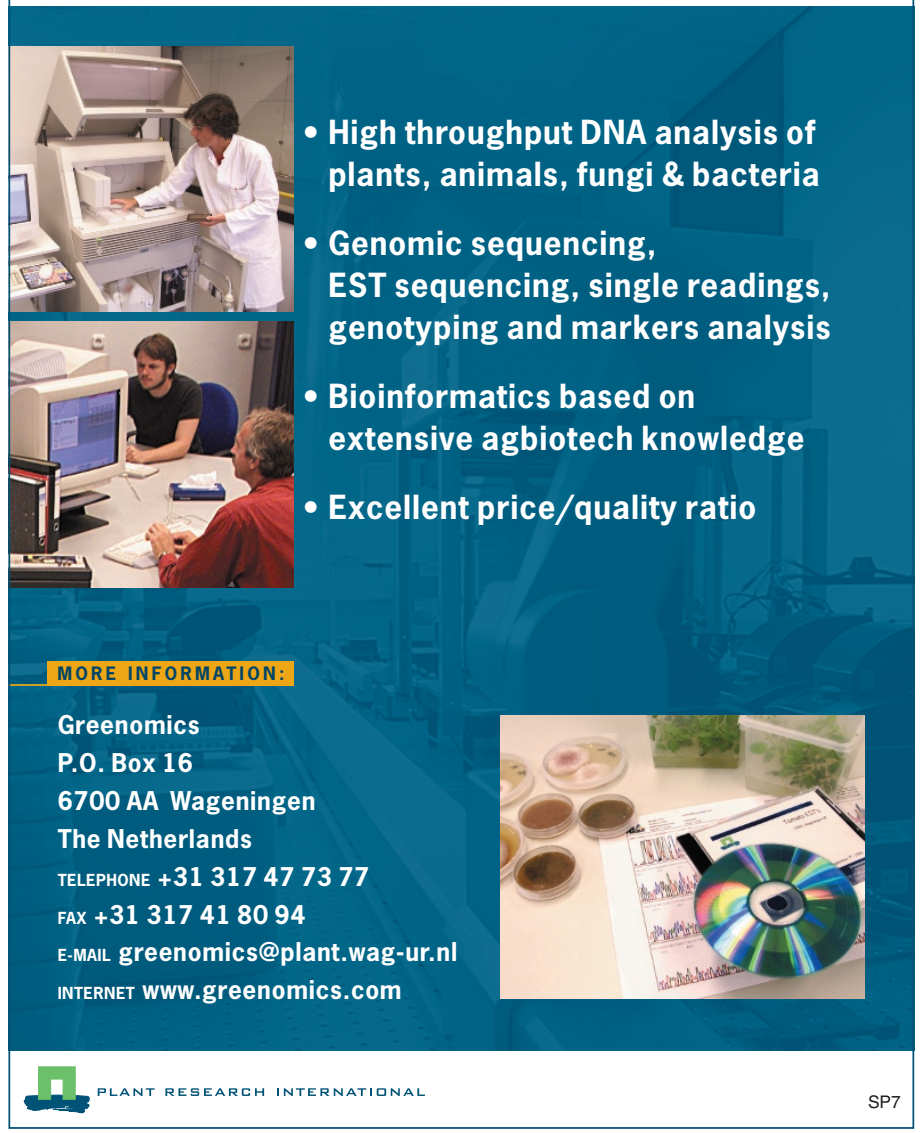

\section{WAGENINGEN CENTRE FOR FOOD SCIENCES}

- WCFS is a strategic research alliance of industry and science.

- WCFS has an ambitious long-term research programme.

- WCFS does research on human nutrition and on structure, functionality and processing of foods.

- WCFS is looking for motivated PhD students and Postdocs.

\section{- WCFS is located in the heart of the fast-growing Wageningen Food Valley.}

Website: www.wcfs.nl Tel. +31317485383 Fax +31 317485384

Postbox 557, 6700 AN Wageningen, The Netherlands 


\section{SPOTLIGHT ON}

The NEIMERIANDS

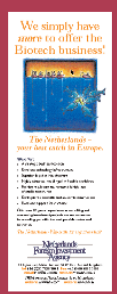

ADVERTISERS INDEX

ACADEMIC BIOMEDIGAL CENTRE -

UTRECHT UNIVERSITY

phone +3130 2539111

BIOMED CITY GRONINGEN

phone +31 505214507

CRUCELL

phone +31 715248701

GENENCOR INCORPORATED

phone +31 715686168

GREENOMICS

phone +31 317477377

ISOTIS

phone +3130229 5229

LEIDEN BIOSCIENCE PARK

phone +3171 5187114

NETHERLANDS FOREIGN INVESTMENT AGENCY phone +442072251074

PEPSCAN SYSTEMS

phone +31 320237200

PHARMING GROUP

phone +31 715247431

PLANT RESEARCH INTERNATIONAL

phone +31 317477017

WAGENINGEN CENTRE FOR FOOD SCIENCE phone +31 317485383

INSTITUTE FOR ANIMAL SCIENCE

\& HEALTH-ID LELYSTAD

phone +31 320238238

WAGENINGEN UNIVERSITY AND

RESEARCH CENTRE

phone +31 317489111
WEBSITE

PACE

www.abc.uu.nl

www.biomedcity.nl

www.crucell.com

www.genencor.com

www.greenomics.com

www.isotis.com

m.martens@leiden.nl

www.nfia.co.uk

www.pepscan.nl

www.pharming.com

www.plant.wageningen-ur.nl 6

www.wcfs.nl

www.wageningen-ur-nl

www.wageningen-ur.nl
12

6

8

9

$4+5$

10

12

11

12

6

10

7

6
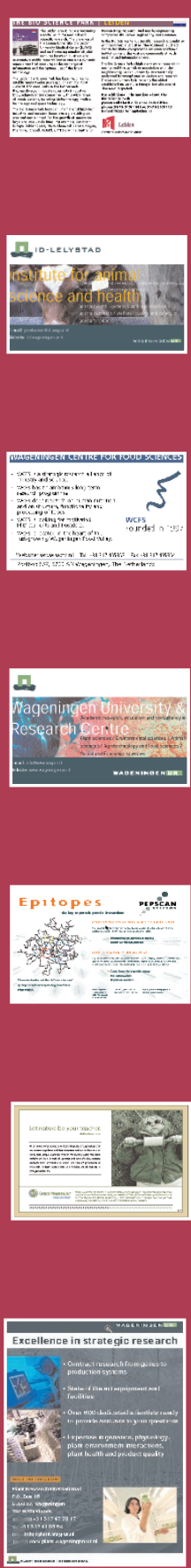

?
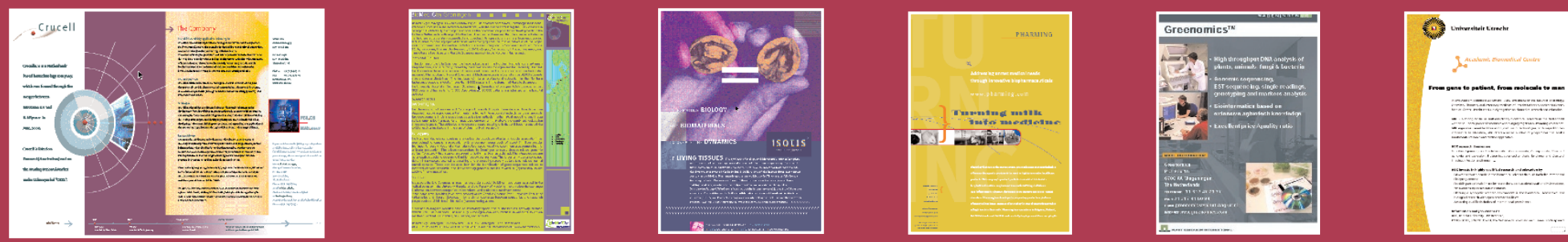